\title{
Change of Tympanogram after Chronic Otitis Media Surgery
}

\author{
Byung-Gil Choi ${ }^{1}$, Ji-Soo Lee ${ }^{1}$, Sung-Kwang Hong ${ }^{1,2}$, Hyo-Jeong Lee ${ }^{1,2}$, and Hyung-Jong Kim ${ }^{1,2}$ iD \\ ${ }^{1}$ Departments of Otorhinolaryngology-Head and Neck Surgery, ${ }^{2}$ Laboratory of Brain \& Cognitive Sciences for Convergence Medicine, \\ Hallym University College of Medicine, Anyang, Korea
}

만성중이염 수술 후 고실도의 변화

최병길 ${ }^{1} \cdot$ 이지수 $^{1} \cdot$ 홍성광 $^{1,2} \cdot$ 이효정 ${ }^{1,2} \cdot$ 김형종 $^{1,2}$

한림대학교 의과대학 이비인후-두경부외과학교실, ${ }^{1}$ 뇌인지융합의학연구소 ${ }^{2}$

Received January 22, 2019

Revised May 10,2019

Accepted May 16, 2019

Address for correspondence

Hyung-Jong Kim, MD, PhD

Department of Otorhinolaryngology-

Head and Neck Surgery,

Hallym University

College of Medicine,

22 Gwanpyeong-ro 170beon-gil,

Dongan-gu, Anyang 14068, Korea

Tel $+82-31-380-3849$

Fax $+82-31-386-3860$

E-mail hjk1000@hallym.or.kr
Background and Objectives Pre-operative eustachian tube function (ETF) is an important factor for the postoperative success after tympanoplasty, though much debates have been reported. In this study, we investigated the tympanogram changes after tympanoplasty, indirectly checking up ETF, to find out the relationship between tympanogram changes and associated factors of tympanoplasty.

Subjects and Method Included in this study were 238 cases of tympanoplasty (canal wall up mastoidectomy with tympanoplasty type I or tympanoplasty type I only) performed by one surgeon for chronic otitis media from January, 2012 to June, 2017. In all cases, tympanometric tests were undertaken at one month, three month, six month, and one year post-operatively, and pure tone audiometry tests were taken at 1 year, post operatively.

Results The average hearing level and air-bone gap were $41.8 \pm 19.7 \mathrm{~dB}$, and $17.1 \pm 9.3 \mathrm{~dB}$, pre-operatively, and $29.9 \pm 21.1 \mathrm{~dB}$, and $6.9 \pm 8.5 \mathrm{~dB}, 1$ year post-operatively, respectively. Most of the cases showed improvement in hearing. The results of tympanometry showed that hearing improvement was greater for the A type than for the B or C type $(p<0.001)$. The smaller the size of the tympanic membrane was, the higher, the type A tympanogram appeared to be ( $p=$ $0.008)$.

Conclusion The estimation of pre-operative ETF using post-operative tympanogram changes can give insight to the degree and process of recovery of the normal middle ear after tympanoplasty.

Korean J Otorhinolaryngol-Head Neck Surg 2019;62(10):554-61

Key Words Eustachian tube function · Prognosis · Tympanometry · Tympanoplasty.

\section{서 론}

만성중이염의 수술로서 유돌절제술은 유양동 내 병변을 제거하고, 함기 공간 확보를 통해 급격한 중이 내 압력변화 를 완충하는 효과가 있으며 고실성형술은 고막과 이소골을 복원하고, 정원창에서 자극음의 위상차를 유지하는 효과가

This is an Open Access article distributed under the terms of the Creative Commons Attribution Non-Commercial License (https://creativecommons.org/licenses/by-nc/4.0) which permits unrestricted non-commercial use, distribution, and reproduction in any medium, provided the original work is properly cited.
있다. ${ }^{1,2)}$ 국내외 선행연구에서 만성중이염의 수술결과의 중요 한 예후인자로서 이관기능이 제시되었으며, 성공적인 결과를 얻기 위해서는 술 전 정확한 이관기능의 평가가 필수적이다. 이관기능의 평가는 Valsalva 이관통기법, Sniff test, Manometry법, Sonotubometry, 내시경 소견, Xe-Scintigraphy 및 반 대측 귀의 중이 소견을 통해 추측할 수 있지만, 술 전 이관기 능의 정량적인 평가에 대한 신뢰도에는 논란이 있다. ${ }^{3-10)}$ 술 전 이관기능의 연구에서 Valsalva 이관통기법을 통해 양성인 군에서 술 후에 더 나은 예후를 보였으나 통계적으로는 유의 
하지 않았고, ${ }^{3)}$ 이관기능부전이 청력의 예후와 관계없음을 보 고한 연구도 있다.1112) 이는 이관기능에 대한 정량적 평가의 어려움으로 인해 발생한 상반되는 결과인 것으로 생각되고, 이에 술 후 예후와 연관성이 있는 압력조절 소견을 이용하여 간접적으로 이관기능을 추정할 수 있는 연구들이 보고되었 다. 선행연구에서 중이점막 상태에 따른 재천공률의 관계를 통해 중이점막 소견을 이용하여 이관기능의 간접적인 평가가 가능함을 발표하였고, ${ }^{4}$ 중이강의 상태를 간접적으로 평가할 수 있는 지표로서 고실도(tympanogram, 고막운동성계측)를 제시하였으며, ${ }^{5)}$ 다른 연구에서는 $\mathrm{A}$ 형 술 후 고실도를 보인 군 에서 청력개선이 유의하게 높음을 보이며 정상 고실도와 건 강한 중이강 형성과의 연관성을 보고한 바 있다. ${ }^{6}$

본 연구의 목적은 만성중이염에서 고막재건술 후에 기간 별로 술 후 고실도를 측정함으로써 간접적으로 고실도로 추 정할 수 있는 이관기능을 판정하고, 술 전 관련인자와의 연관 성이 있는지 역추적하고자 하였다. 이를 위해서 첫째, 술 후 정상 고실도를 보인 군과 비정상 고실도를 보인 군에서 수술 방법이나 술 전 고막천공의 크기 또는 위치에 따른 차이가 있 는지를 알아보았고, 둘째, 정상 고실도 $\mathrm{A}$ 형을 보인 군에서 처 음으로 정상 고실도가 나타나는 술 후 기간을 추적하였으며 추가적으로 셋째, 수술방법 및 술 전 고막천공의 크기와 위 치가 술 후 청력개선에 미치는 영향을 연구하였다.

\section{대상 및 방법}

2012년 1월부터 2017년 6월까지 본원 이비인후과에서 폐 쇄동 유돌절제술 및 1형 고실성형술 혹은 단독으로 1형 고실 성형술을 시행받은 후 1 년 이상 추적 관찰이 가능했던 환자 를 대상으로 수술기록을 포함한 의무기록과 함께 대한이과 학회에서 배포한 중이수술 데이터베이스(2005)에 저장되어 관리된 238예의 자료를 이용하여 후향적 분석을 실시하였다. 대상 환자는 남자 91명(38\%) 여자 147명(62\%)이었고, 연령은 5 세부터 85 세까지 평균 $52.2 \pm 16.1$ 세였다. 본 연구는 본원의 임상시험연구심사위원회(Institutional Review Board)의 검 토와 승인을 얻은 후 진행하였다(HALLYM 2018-11-008001).

모든 환자는 고막과 중이점막의 염증이 없는 상태에서 수 술을 시행하였고, 이루가 있었던 경우 항생제 치료 후 3개월 이상 염증 없이 유지된 경우 수술을 시행하였다. 수술 전 측 두골 전산단층촬영을 시행하여 유양동 함기화의 정도에 따 라 함기형(pneumatic), 판상형(diploic) 및 경화형(sclerotic) 으로 분류하였고, 대부분의 경우 함기형이면 단독으로 1형 고실성형술을 시행하고, 판상형이나 경화형이면 유돌절제술
을 동반한 고실성형술을 시행하였다. 본 연구는 1 인의 술자 에 의한 수술례만 포함하였으며 모든 예에서 측두근 근막을 이식재료로 사용하였고, underlay 이식을 하였으며 중이강 및 외이도 내 항생제를 적신 gelfoam을 패킹 후 2주간 유지 하였다. 수술 후 1 개월, 3 개월, 6 개월, 1 년에 추적하여 이경 검 사와 표준순음청력 검사 및 고실도 검사를 시행하였다.

1 년 이상 추적 관찰이 되지 않거나 추적 기간 중 표준순음 청력 검사 및 고실도 검사 결과가 누락되었거나 수술 후 고막 천공이 재발한 경우, 개방동 유돌절제술을 받은 경우는 연구 대상에서 제외하였다.

고실도 검사는 GSI Middle ear analyzer(Grason Stadler, Eden Prairiem, MN, USA)을 사용하여 측정했으며 외이도의 압력변화(+200 -400 mmH $2 \mathrm{O})$ 에 따라 변하는 고막의 탄성 범위(compliance)로 고실도를 구하였다. 형태에 따라 -100에 서 $+100 \mathrm{mmH}_{2} \mathrm{O}$ 에서 최대 탄성이 관찰되는 것을 $\mathrm{A}$ 형, 최대 탄성이 $-101 \mathrm{mmH}_{2} \mathrm{O}$ 이하에서 나타나는 것을 $\mathrm{C}$ 형으로, 수 평이나 궁형으로 나타나 최대 탄성이 뚜렷하지 않은 경우를 $\mathrm{B}$ 형으로 하였고, 수술 후 정상 고실도인 $\mathrm{A}$ 형을 나타나는 최 초 기간을 기록하고 수집하였다.

본 연구에서는 술 후 고실도의 관계를 분석하기 위해 고실 도 $\mathrm{A}$ 형을 정상, $\mathrm{B}$ 형과 $\mathrm{C}$ 형을 비정상군으로 분류하였고, 영 향요인으로 수술방법, 천공의 크기, 천공의 위치와의 관계를 확인하기 위해 chi-square test 및 Fisher's exact test를 시행 하였다. 수술방법으로 유돌절제술 및 고실성형술을 받은 예 와 단독으로 고실성형술을 받은 예로 구분하였고, 술 전 고막 천공의 크기는 내시경고막 사진상 천공의 면적이 전체의 $25 \%$ 이하를 소천공, $25 \sim 75 \%$ 사이를 중등도 천공, $75 \%$ 이상을 대 천공으로 정의하였고, 천공의 위치는 추골병을 기준으로 앞 쪽은 전방천공, 뒤쪽은 후방천공, 앞뒤에 걸쳐 있으면 중심천 공으로 정의하였다. 술 전 고막천공의 크기와 위치에 따른 A 형 정상 고실도가 처음으로 나타나는 수술 후 기간을 조사하 였으며, 관계를 chi-square test 및 Fisher's exact test를 시행 하였다. 그리고 미국 이비인후과학회 기준(AAO-NHS standard, 1995)을 따라 순음청력역치 $0.5,1,2,3 \mathrm{kHz}$ 의 평균인 4 분법을 이용하여 평균역치를 기도청력과 골도청력별로 계 산하였고, 기도-골도역치차를 수술 전과 술 후 1년에 비교하 여 청력의 개선 정도를 조사하여 수술방법은 t-test, 고막천공 의 크기와 위치와의 연관성에 analysis of variance를 통해 분석하였다.

통계학적 검사는 IBM PC용 SPSS program version 20(IBM Corp., Armonk, NY, USA)을 사용하였고, $p$ 값이 0.05 미만 일 때 유의한 차이가 있다고 판정하였다. 


\section{결 과}

술 전 고막과 술 후 1 년 추적 관찰 후의 대표적인 고막 소 견들은 Fig. 1과 같다. 모든 예의 술 전 표준순음청력 검사상 청력역치는 각각 $41.8 \pm 19.7 \mathrm{~dB}$ 였고, 기도-골도차이는 $17.1 \pm$ $9.3 \mathrm{~dB}$ 였으며, 술 후 1 년 후 청력역치는 $29.9 \pm 21.1 \mathrm{~dB}$ 였고, 기 도-골도차이는 $6.9 \pm 8.5 \mathrm{~dB}$ 으로 술 후 청력역치 및 기도-골 도차이에서 개선을 보였다(Table 1).

\section{고실도의 분석}

모든 예에서 술 후 1 년간 추적 관찰하였을 때 고실도 결과 는 A형 163명(69\%), B형 58명(24\%) 및 C형 17명(7\%)이었고, 술 후 A형 고실도를 보인 환자들의 술 전 천공의 크기의 분포 는 소천공(48\%), 중등도 천공(45\%), 대천공(7\%)이었으며, 술
후 A형 고실도를 보이는 데까지 소요기간은 소천공 3.6개월, 중등도 천공 4.3개월, 대천공 4.4개월이었고 술 후 고실도 A 형이 나타나기까지의 기간은 평균 $3.9 \pm 3.3$ 개월이었다(Fig. 2). 술 후 1 개월, 3 개월, 6 개월, 1 년간 술 후 A형 고실도의 분포 및 변화, 상기 기간별 술 후 고실도 $\mathrm{A}, \mathrm{B}, \mathrm{C}$ 형의 분포를 각각 그 래프로 나타내었다(Fig. 3).

\section{수술방법과 술 후 고실도의 관계}

본 연구에서 수술방법으로 유돌절제술 및 고실성형술을 받은 예는 140예(59\%)였고, 단독으로 고실성형술을 받은 환 자는 98예(41\%)였다. 고실도 A형을 정상으로 하고, B형과 C 형을 비정상으로 구분하여 유돌절제술 동반여부, 즉, 단독 고실성형술과 유돌절제술 동반 고실성형술을 비교하였을 때 수술방법에 따른 술 후 정상고실도 $\mathrm{A}$ 형의 비율의 차이는 통

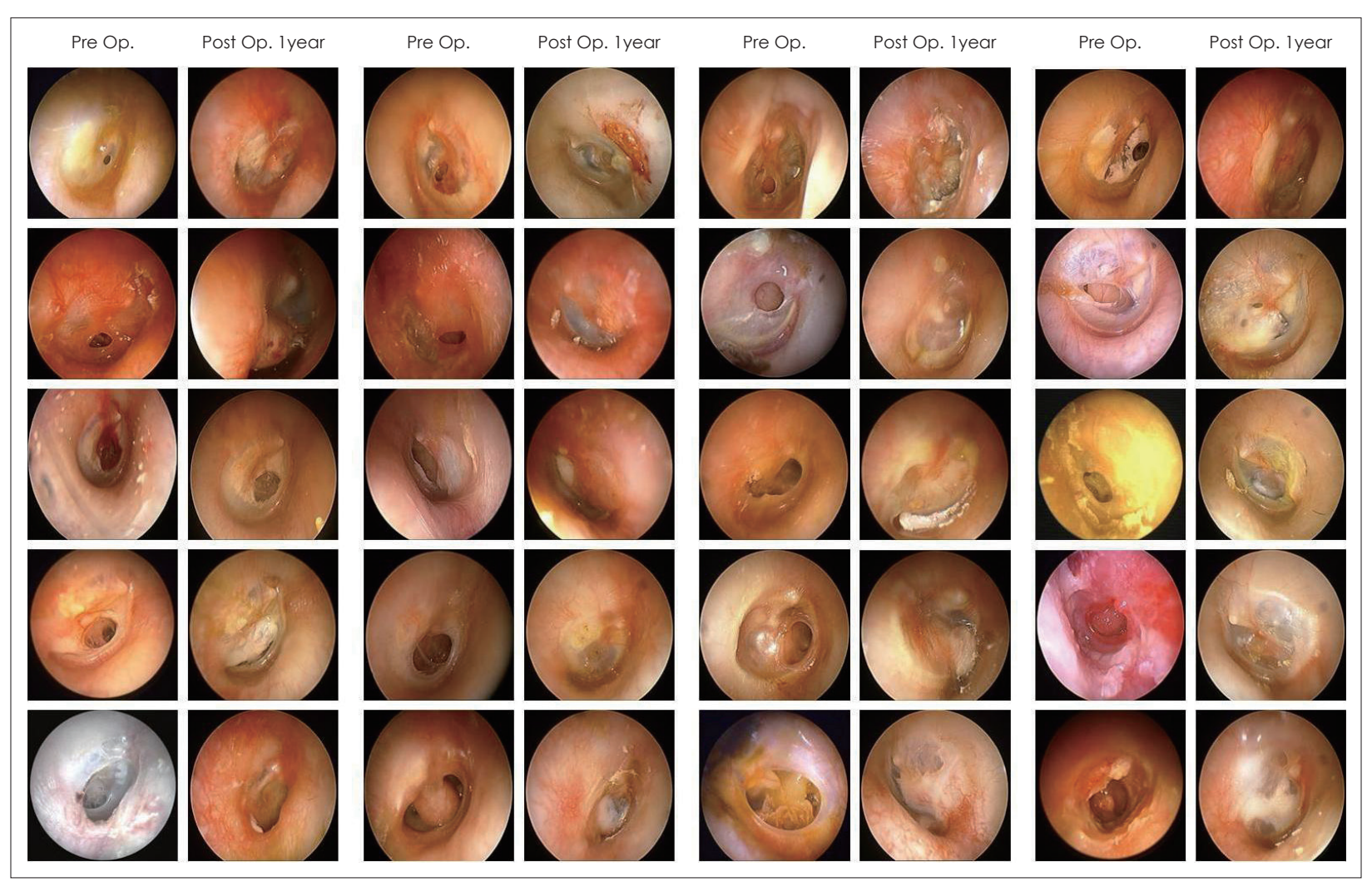

Fig. 1. Pre Op. and post Op. tympanic membrane findings at 1year. Op: operative.

Table 1. Distribution of preoperative and postoperative air-bone gap and postoperative hearing gain

\begin{tabular}{ccccc}
\hline Air-bone gap & Preoperative $(n, \%)$ & Postoperative $(n, \%)$ & Hearing gain & Postoperative $(n, \%)$ \\
\hline$<10$ & $63(27)$ & $174(73)$ & $<0$ & $24(10)$ \\
$10-20$ & $93(39)$ & $46(19)$ & $0-10$ & $72(30)$ \\
$20-30$ & $62(26)$ & $12(5)$ & $10-20$ & $103(43)$ \\
$30<$ & $20(8)$ & $6(3)$ & 20 & $39(17)$ \\
Average $(\mathrm{dB})$ & $17.1 \pm 9.3$ & $6.9 \pm 8.5$ & & $11.9 \pm 10.4$ \\
\hline
\end{tabular}

$\mathrm{n}$ : number of patients 

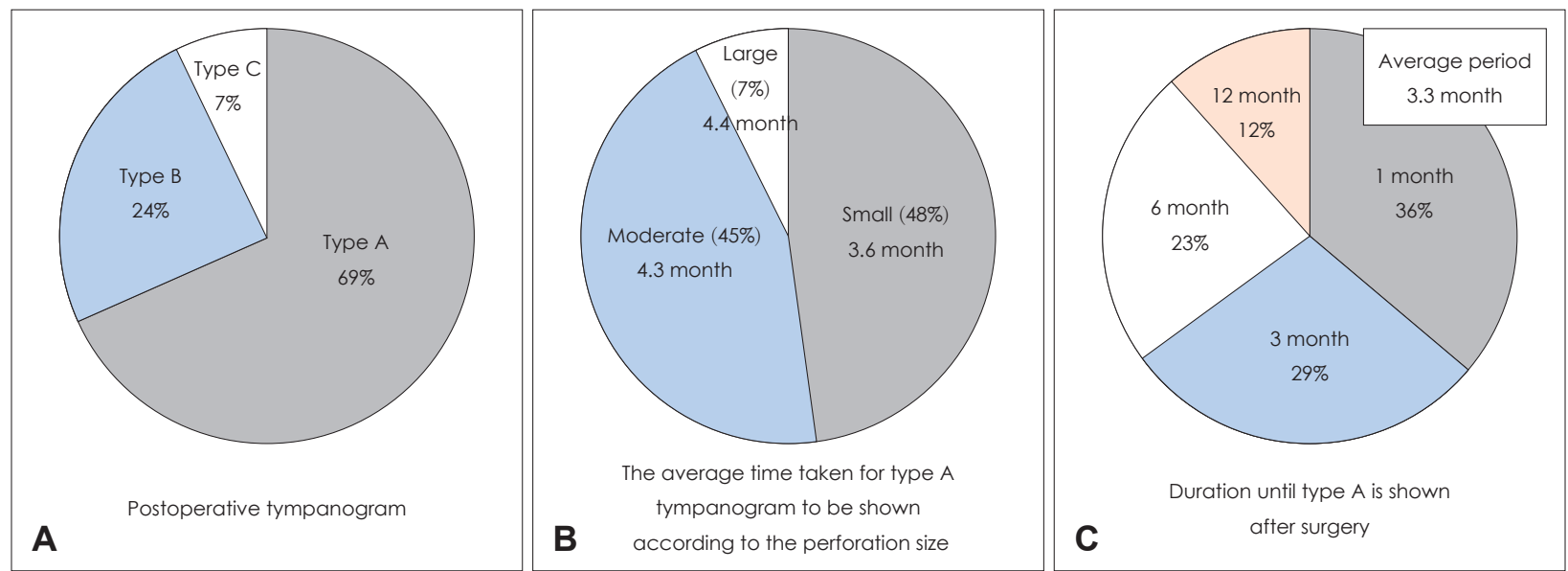

Fig. 2. Analysis of postoperative tympanogram. Postoperative tympanogram (A). The average time taken for type A tympanogram to be shown according to the perforation size (B). The duration until type A tympanogram is shown after surgery (C).

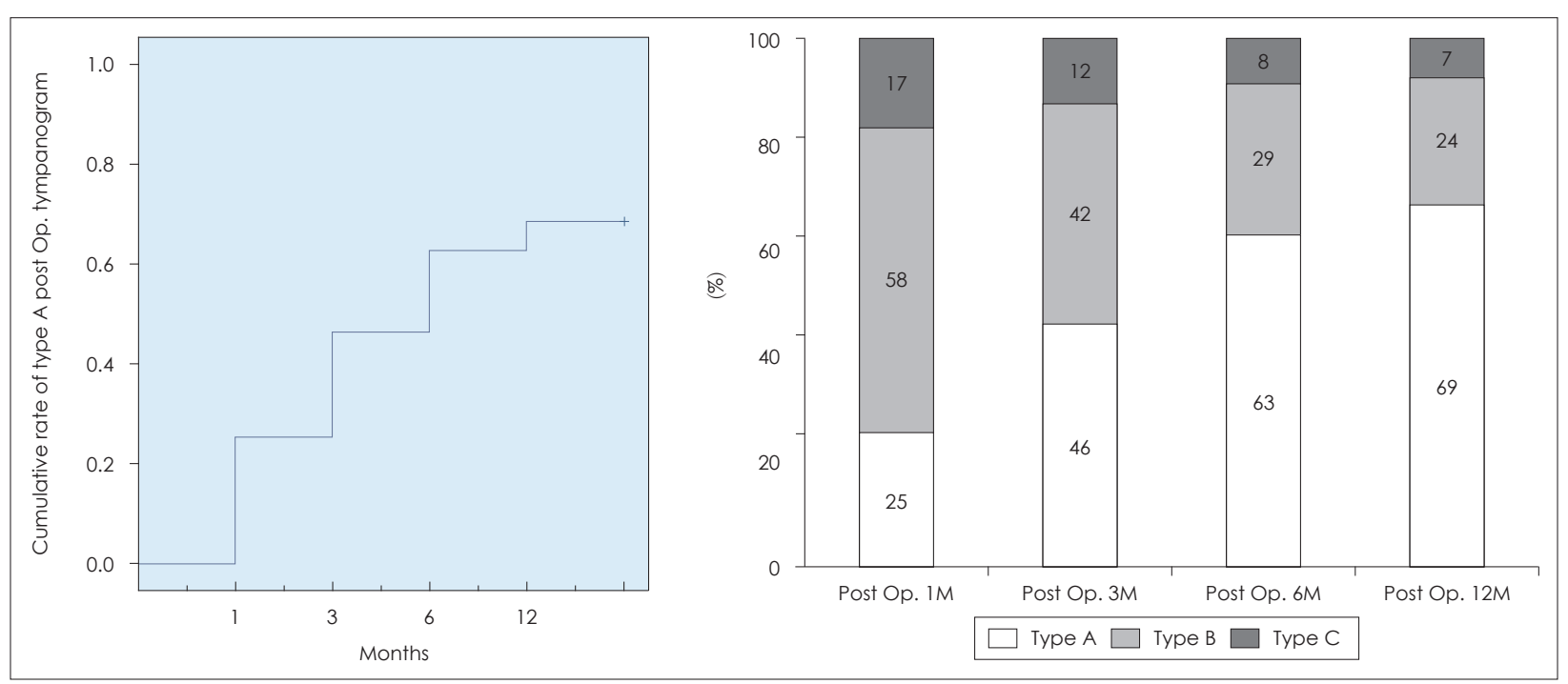

Fig. 3. Changes of postoperative tympanogram with time. Op: operative.

계적으로 유의하지 않았다 $(p=0.414)$.

\section{천공의 크기 및 위치와 술 후 고실도의 관계}

술 전 고막천공의 위치는 전방 78예(33\%), 후방 27예(11\%) 및 중심천공 133 예(56\%)를 보였고, 천공의 크기는 소천공 102예(43\%), 중등도 천공 109예(46\%) 및 대천공 27예(11\%)의 분포를 보였다. 고실도 $\mathrm{A}$ 형을 정상, $\mathrm{B}$ 형과 $\mathrm{C}$ 형을 비정상군으 로 구분하여 고막천공의 크기에 따라 분석하였을 때, 천공의 크기가 작을수록 정상 고실도의 비율이 높았으며 $(p=0.008)$, 소천공, 중등도 천공 및 대천공에서 정상 고실도로의 회복기 간은 각각 $3.6 \pm 3.3$ 개월, $4.3 \pm 3.4$ 개월 및 $4.4 \pm 3.2$ 개월로 측정 되었다.

고막천공의 위치와 술 후 A형 고실도 비율 간의 분석에서 위치로 인한 교란변수를 통제하기 위해 중심천공은 제외하
고, 전방천공과 후방천공에 대해서만 비교 분석하였을 때 천 공의 위치에 대한 술 후 정상 고실도 비율 간의 차이는 통계 적으로 유의하지 않았다 $(p=0.920)$ (Table 2).

\section{술 후 고실도에 따른 청력변화와의 차이}

술 후 고실도가 $\mathrm{A}$ 형으로 회복된 군에서 측정하였을 때 술 전 청력역치와 기도-골도차이는 $40.2 \pm 19.1 \mathrm{~dB}$ 와 $15.8 \pm 8.8$ $\mathrm{dB}$ 이었고, 술 후 1 년 후 $27.1 \pm 18.5 \mathrm{~dB}$ 과 $4.8 \pm 6.6 \mathrm{~dB}$ 로 측정 되었고, $\mathrm{B}$ 형에서는 술 전 청력역치와 기도-골도차이는 각각 $45.2 \pm 19.3 \mathrm{~dB}$ 과 $20.3 \pm 9.1 \mathrm{~dB}$ 이었고, 술 후 $36.7 \pm 24.3 \mathrm{~dB}$ 과 $11.9 \pm 11.0 \mathrm{~dB}$ 이었으며 $\mathrm{C}$ 형에서는 술 전 청력역치와 기도-골 도차이는 각각 $45.7 \pm 25.5 \mathrm{~dB}$ 과 $18.2 \pm 11.7 \mathrm{~dB}$ 이었고, 술 후 $34.4 \pm 27.1 \mathrm{~dB}$ 과 $9.5 \pm 7.2 \mathrm{~dB}$ 로 모든 군에서 술 후 청력역치 와 기도-골도차이의 호전을 보였다. 술 후 $\mathrm{A}$ 형 고실도군이 각 
각 술 후 B형, $\mathrm{C}$ 형 고실도군에 비해 통계적으로 유의하게 청 력역치에서 호전을 보였으며, 기도-골도차이에서 전체적으로 호전소견 보이고 있으나 A형 고실도와 B형 고실도와 다르게 A형과 C형에선 통계적으로 유의하지 않았다(Fig. 4). A형 고 실도를 보인 군을 정상군, $\mathrm{B}$ 형 또는 $\mathrm{C}$ 형의 고실도를 보인 군 을 비정상군으로 분류하여 비교하였을 때 정상군에서 술 후 더 큰 청력의 개선이 있었다 $(p<0.001, p=0.020)$ (Table 2).

\section{청력변화에 영향을 미치는 인자분석}

수술방법, 술 전 고막천공의 크기 및 위치 인자가 술 후 청 력변화에 영향을 주는지 분석하였다. 수술방법으로서 유돌 절제술 및 고실성형술을 받은 군의 청력역치 및 기도-골도차
이는 술 전 각각 $46.3 \pm 19.2 \mathrm{~dB}$ 및 $19.8 \pm 9.1 \mathrm{~dB}$ 에서 술 후 1 년 후 $32.6 \pm 20.4 \mathrm{~dB}$ 및 $8.2 \pm 8.6 \mathrm{~dB}$ 로 호전되었고, 단독으로 고실성형술군에서는 $35.5 \pm 18.8 \mathrm{~dB}$ 및 $13.2 \pm 8.1 \mathrm{~dB}$ 에서 26.2 $\pm 21.6 \mathrm{~dB}$ 및 $4.9 \pm 7.9 \mathrm{~dB}$ 로 모두 호전된 결과를 보였으며 통 계적으로 군 간의 차이는 유의하진 않았다 $(p=0.558, p=0.721)$. 술 전 고막천공의 크기로서 비교하였을 때 소천공의 청력역 치 및 기도-골도차이는 술 전 각각 $38.3 \pm 19.3 \mathrm{~dB}$ 및 $14.1 \pm 8.7$ $\mathrm{dB}$ 에서 술 후 1 년 후 $27.8 \pm 22.0 \mathrm{~dB}$ 및 $5.8 \pm 8.5 \mathrm{~dB}$, 중등도 천공은 술 전 각각 $43.9 \pm 20.7 \mathrm{~dB}$ 및 $18.4 \pm 9.1 \mathrm{~dB}$ 에서 술 후 1 년 후 $31.4 \pm 20.9 \mathrm{~dB}$ 및 $7.0 \pm 8.1 \mathrm{~dB}$, 대천공은 술 전 각각 $46.6 \pm 15.1 \mathrm{~dB}$ 및 $23.4 \pm 8.2 \mathrm{~dB}$ 에서 술 후 1년 후 $32.4 \pm 17.8$ $\mathrm{dB}$ 및 $10.7 \pm 9.4 \mathrm{~dB}$ 를 보였으며, 대천공군에서 소천공군보다

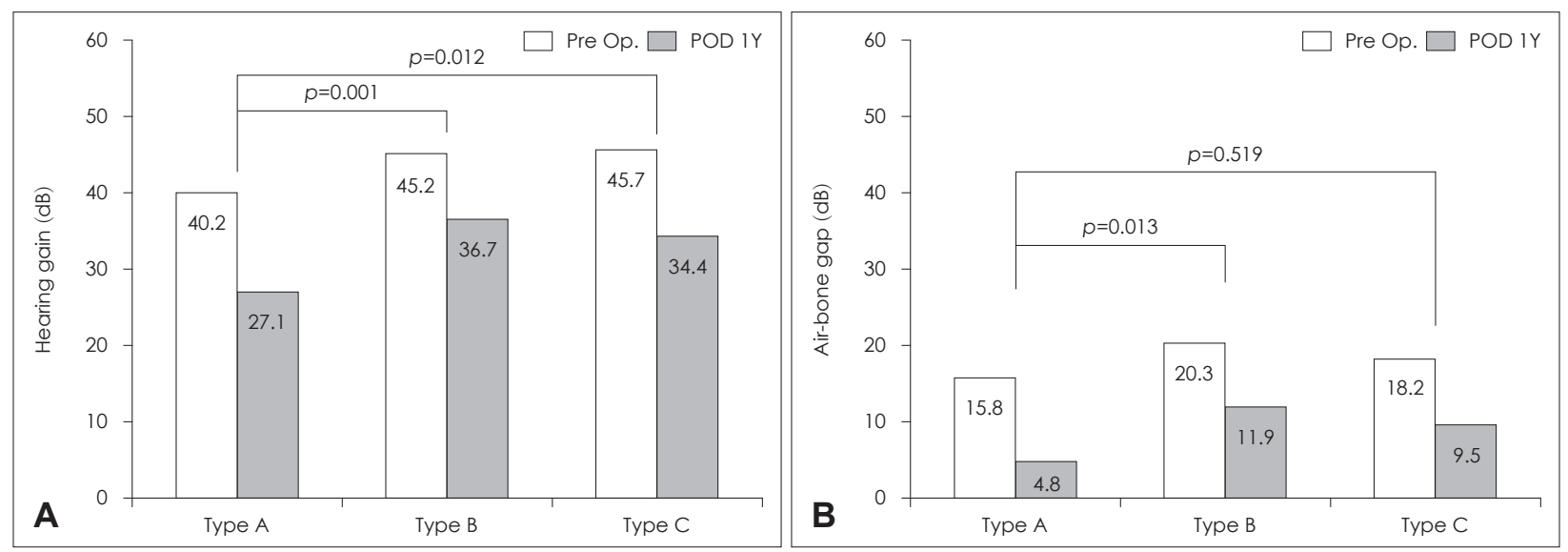

Fig. 4. Association between the type of post Op. tympanogram and hearing results. Assessment of hearing gain (A). Assessment of airbone gap (B). Op: operative.

Table 2. Operative data influencing postoperative tympanogram

\begin{tabular}{|c|c|c|c|c|}
\hline & \multicolumn{3}{|c|}{ Results of tympanogram } & \multirow{2}{*}{$p$-value } \\
\hline & Type A & Type B & Type C & \\
\hline \multicolumn{5}{|l|}{ Postoperative audio (dB) } \\
\hline$A B G$ & $4.8 \pm 6.6$ & $11.9 \pm 11.0$ & $9.5 \pm 7.2$ & \multirow{2}{*}{$\begin{array}{r}0.020^{*} \\
<0.001^{*}\end{array}$} \\
\hline Hearing gain & $13.0 \pm 8.8$ & $8.5 \pm 12.9$ & $11.4 \pm 12.5$ & \\
\hline \multicolumn{5}{|l|}{ Factor I } \\
\hline Operative method, n (\%) & & & & \multirow[t]{3}{*}{0.414} \\
\hline CWUM C Tl $(n=140)$ & $93(67)$ & $34(24)$ & $13(9)$ & \\
\hline $\mathrm{Tl}(\mathrm{n}=98)$ & $70(71)$ & $24(25)$ & $4(4)$ & \\
\hline \multicolumn{5}{|l|}{ Factor II } \\
\hline Perforation size, n (\%) & & & & \multirow[t]{4}{*}{$0.008^{*}$} \\
\hline Small perforation $(n=102)$ & $78(76)$ & $19(19)$ & $5(5)$ & \\
\hline Moderate perforation $(n=109)$ & $74(68)$ & $27(25)$ & $8(7)$ & \\
\hline Large perforation $(n=27)$ & $13(48)$ & $10(37)$ & $4(15)$ & \\
\hline \multicolumn{5}{|l|}{ Factor III } \\
\hline Perforation location, n (\%) & & & & \multirow[t]{4}{*}{0.920} \\
\hline Anterior perforation $(\mathrm{n}=78)$ & $57(73)$ & $17(22)$ & $4(5)$ & \\
\hline Posterior perforation $(\mathrm{n}=27)$ & $20(74)$ & $4(15)$ & $3(11)$ & \\
\hline Central perforation $(n=133)$ & $86(64)$ & $37(28)$ & $10(8)$ & \\
\hline
\end{tabular}

$* p<0.05$. ABG: air-bone gap, CWUM: canal wall up mastoidectomy, $\mathrm{Tl}$ : tympanoplasty type $\mathrm{l}, \mathrm{n}$ : number of patients 
청력역치 호전의 정도가 유의하게 큰 결과를 보였으나 $(p=$ 0.008), 기도-골도차이 호전의 정도에서는 유의한 차이를 보 이지 않았다 $(p=0.310)$.

술 전 고막천공의 위치로서 비교하였을 때 전방천공의 청력 역치 및 기도-골도차이는 술 전 각각 $37.6 \pm 19.3 \mathrm{~dB}$ 및 $15.1 \pm$ $8.4 \mathrm{~dB}$ 에서 술 후 1 년 후 $27.6 \pm 19.2 \mathrm{~dB}$ 및 $5.2 \pm 7.0 \mathrm{~dB}$, 후방 천공은 술 전 각각 $36.6 \pm 13.9 \mathrm{~dB}$ 및 $13.9 \pm 8.2 \mathrm{~dB}$ 에서 술 후 1년 후 $24.3 \pm 18.6 \mathrm{~dB}$ 및 $6.1 \pm 10.3 \mathrm{~dB}$, 중심천공은 술 전 각 각 $45.4 \pm 20.4 \mathrm{~dB}$ 및 $18.9 \pm 9.6 \mathrm{~dB}$ 에서 술 후 1 년 후 $32.6 \pm$ $22.4 \mathrm{~dB}$ 및 $8.0 \pm 8.8 \mathrm{~dB}$ 로 술 후 청력역치 및 기도-골도차이 에서 전반적인 호전은 보였으며, 교란변수를 통제하기 위해 중심천공을 제외한 전방천공과 후방천공에 대해 비교하였을 때 두 군 간의 차이는 통계적으로 유의하지 않았다 $(p=0.121$, $p=0.072$ )(Table 3).

\section{고 찰}

만성중이염의 술 후 예후를 추정할 수 있는 관련인자에 대 해 국내외 연구자들에 의해 보고되고 있다. 선행 연구에서 술 전 점막상태를 중요한 관련인자로 보고하였고, ${ }^{4)}$ 다른 연구에 서는 술 후 중이강의 점막상태, 추골의 보존여부, 외이도 보 존여부, 고막천공의 크기나 위치 등을 관련인자로 보고하였 으며, 대부분의 연구자들은 이관의 원활한 기능을 중요한 술후 예후의 인자로서 동의하고 있다. ${ }^{3-10)}$ Yoon과 Yang ${ }^{13)}$ 은 이관기능을 간접적으로 평가할 수 있는 지표로서 중이의 점 막상태를 제시하였으나 현재까지도 신뢰도 높은 정량적인 이

Table 3. Audiometric results according to various ractors

\begin{tabular}{lcc}
\hline \multirow{2}{*}{ Related factors } & \multicolumn{2}{c}{ Audiometry results } \\
\cline { 2 - 3 } & $\begin{array}{c}\text { Air-bone gap } \\
(\mathrm{dB})\end{array}$ & $\begin{array}{c}\text { Hearing gain } \\
(\mathrm{dB})\end{array}$ \\
\hline Operative method & $8.2 \pm 8.6$ & $13.6 \pm 10.9$ \\
CWUM C T1 $(\mathrm{n}=140)$ & $4.9 \pm 7.9$ & $9.5 \pm 8.9$ \\
T1 $(\mathrm{n}=98)$ & 0.558 & 0.721 \\
p-value & & \\
Perforation size, $\mathrm{n}$ & $5.7 \pm 8.5$ & $10.4 \pm 10.9$ \\
Small perforation $(\mathrm{n}=102)$ & $7.0 \pm 8.1$ & $12.6 \pm 8.9$ \\
Moderate perforation $(\mathrm{n}=109)$ & $10.7 \pm 9.4$ & $14.2 \pm 12.9$ \\
Large perforation $(\mathrm{n}=27)$ & 0.310 & $0.008^{*}$ \\
p-value & & \\
Perforation location, $\mathrm{n}$ & $5.2 \pm 7.0$ & $10.1 \pm 9.8$ \\
Anterior perforation $(\mathrm{n}=78)$ & $6.1 \pm 10.3$ & $12.3 \pm 12.9$ \\
Posterior perforation $(\mathrm{n}=27)$ & $8.0 \pm 8.8$ & $12.8 \pm 10.1$ \\
Central perforation $(\mathrm{n}=133)$ & 0.072 & 0.121 \\
\hline p-value & &
\end{tabular}

*p<0.05. CWUM: canal wall up mastoidectomy, $\mathrm{Tl}$ : tympanoplasty type I, n: number of patients
관기능 평가방법에 대해서는 논란의 여지가 있는 실정이다.

본 연구는 연구결과의 교란변수를 최소화하기 위해 동일 한 집도의, 수술방법(유돌절제술 동반 고실성형술 또는 단독 고실성형술), 이식재료, underlay 이식법을 받은 환자를 대상 으로 일정기간 이상 추적한 결과를 수집하였다. 정상 이관기 능을 시사하는 $\mathrm{A}$ 형의 정상 고실도를 보인 군에서 $\mathrm{B}$ 형이나 C 형의 고실도를 보인 군보다 술 후 청력의 개선이 큰 것으로 나타났고, 정상 고실도가 처음 나타나기까지 술 후 평균 3.3개 월이 소요되었다.

만성중이염에서 중이강 내 염증은 결과적으로 고막과 이 소골을 통한 원활한 에너지 전달 및 움직임을 저해하여 임피 던스 청력 검사상 B형 혹은 C형 고실도가 나타나게 되며, A 형의 고실도가 나타나는 것으로서 중이강 내 염증이 가라앉 고, 이관통기가 잘 되었음을 간접적으로 추정할 수 있다. 본 연구결과에서 $\mathrm{A}$ 형을 보인 군에서 $\mathrm{B}$ 형 혹은 $\mathrm{C}$ 형의 군에 비해 청력역치와 기도-골도차이의 청력개선도 유의하게 나타났고 $(p<0.001, p=0.020)$, 이는 선행연구의 결과와 유사하였다. ${ }^{7}$ 이 결과는 이관기능이 좋을 것으로 추정되는 $\mathrm{A}$ 형군에서 이관기 능이 떨어지는 $\mathrm{B}$ 형 또는 $\mathrm{C}$ 형에 비해 술 후 기도-골도차이가 개선되었음을 시사한다. $\mathrm{A}$ 형을 나타내는 술 후 기간이 평균 3.3 개월이라는 것은 술 후 중이가 정상화되는 데에 그만한 시간이 소요됨을 의미한다고 볼 수 있으며, 평균 3.3개월 후 청결한 중이강이 형성됨으로써 연쇄적으로 청력의 개선을 보였고 결과적으로 이를 간접적으로 대변해주는 $\mathrm{A}$ 형군에서 저명하게 나타났다.

또한, 본 연구에서는 고막천공의 크기가 작은 군에서 큰 군보다 정상 고실도가 나타나는 비율이 높았고, 고막천공의 크기가 작은 군에서 정상 고실도를 보이기까지 술 후 기간도 짧게 나타나는 것으로 관찰되었다 $(p=0.008)$. 천공의 크기가 작을수록 중이강 내 static compliance의 변화 정도가 적어 정상 고실도로의 회복 비율이 높고, 짧은 기간에 회복이 되 었을 것으로 생각된다. 이 결과는 고막천공이 작은군이 큰군 보다 술 전 이관기능이 더 좋음을 시사하는 새로운 결과라 고 할 수 있다. 반면에, 천공의 크기가 클수록 중이강 내 압 력의 변화가 줄어들게 되며 난원창과 정원창으로 소리 에너 지가 동시에 전달됨으로써 진행파 상쇄(traveling wave cancellation)로 인한 술 전 청력손실이 컸을 것으로 사료되고, 이 에 따라 본 연구에서도 선행연구의 보고와 유사하게 술후 청 력역치의 개선은 천공의 크기가 클수록 컸으며 이는 통계적 으로 유의함을 보였다 $(p=0.008)^{4}{ }^{4}$ 반면에 고막천공의 위치는 중이강 내의 압력 변화에 큰 변화를 초래하지 못할 것으로 생각되며 천공의 위치에 따른 정상 고실도가 나타나는 비율 도 유의한 차이를 보이지 않았다 $(p=0.920)$. 난원창과 정원창 
이 직접적으로 위치한 후방 천공 시 술 후 청력의 변화가 유 의하게 있을 것으로 생각되었으나 예상과 달리 유의하지 않 은 차이를 보이지 않아 흥미로운 결과라고 생각한다. 이는 후방천공에서 난원창과 정원창에 전달되는 소리 에너지로 인한 진행파 상쇄를 일으킬만한 중등도 이상의 천공의 사례 수가 상대적으로 많지 않아 기인한 결과로 추측된다. 본 연 구에서는 선행연구의 결과와 유사하게 천공의 위치에 따른 청력역치의 변화는 통계적으로 유의함을 보이지 않았으며 $\left.(p=0.121){ }^{4}\right)$ 향후 직접적인 위험인자로서의 중심천공과 후방 천공을 재정의하여 구분하고 사례를 보강한 연구가 필요하다.

수술방법, 즉, 동반 유돌절제술 여부에 따라 정상 고실도 를 보이는 비율 $(p=0.414)$ 및 청력역치의 개선 정도 $(p=0.558)$ 의 비교에서는 통계적으로 유의한 차이가 없는 것으로 나타 났으며 이는 유돌절제술 및 고실성형술을 시행한 군도 이소 골의 연쇄상 이상이 없는 제1형 고실성형술을 시행한 경우만 대상으로 하였기 때문으로 사료된다. 술 후 청력변화에서도 술 전에 비해 술 후에 전반적인 청력개선을 보이고 있으나 수 술방법에 따른 차이는 선행연구의 결과와 마찬가지로 나타나 지 않았으며, ${ }^{47,8,14)}$ 이는 술 후 유돌부의 함기화가 청력개선에 큰 역할을 하지 않는 것을 시사하고 정상 고실도는 유돌부 함기화보다는 이관기능에 더 의존함을 추측할 수 있게 한다.

하지만, 유돌절제술을 함께 시행한 군은 고실성형술만 시 행한 군에 비해 유돌부 함기화가 부족했으며, 장기추적 관찰 하였을 때 $\mathrm{A}$ 형 고실도에서 B형 혹은 C형으로 변하고, 개선 되었던 기도-골도차이가 다시 커지는 사례가 본 연구에서도 관찰되었다. Ojala와 Sorri ${ }^{15)}$ 는 고실성형술 후 1년 이내에서 청력개선을 보였던 환자군에서 5년 이상의 장기추적 관찰 시 기도-골도차이가 커짐에 따라 중이점막의 유착 과정이 진행 됨에 따른 결과로 보고하였고, 이는 만성중이염을 않던 환자 들에서 고막재건 이후에도 충분치 않은 이관기능으로 인해 삼출성 중이염이나 유착성 중이염이 발생되는 것을 시사하 며 이런 군에서는 장기적인 추적 관찰을 이용한 중이염의 자 연사적 연구가 필요할 것으로 판단된다.

요약하면 첫째, $\mathrm{A}$ 형 고실도가 나타나는 것은 청결한 중이 강의 상태 및 이관통기가 잘 되고 있음을 간접적으로 대변해 주는 지표로 $\mathrm{A}$ 형을 나타내기까지 평균 3.3 개월이 소요되었 으며, $\mathrm{B}$ 형 혹은 $\mathrm{C}$ 형을 보인 군에 비해 통계적으로 유의한 청 력의 개선을 보였다. 둘째, 천공의 크기가 작을수록 $\mathrm{A}$ 형으로 의 회복률이 통계적으로 유의하게 높았으며, A형을 보이기까 지의 소요기간도 짧았다. 셋째, 천공의 크기가 클수록 청력 의 개선은 통계적으로 유의하게 호전되었으며, 넷째, 천공의 위치에 따른 $\mathrm{A}$ 형 고실도로의 회복 및 청력의 개선은 통계적 으로 유의하지 않았다. 마지막으로 시행한 유돌절제술 여부
에 따라 고실도 $\mathrm{A}$ 형으로의 회복률 및 청력 개선에서 통계적 으로 유의하지 않았다. 하지만, 만성중이염의 수술적 치료 후 장기적으로 고실도 및 청력에 대한 추적 관찰은 필요하다.

결론적으로 임피던스 청력 검사상 고실도 검사를 통해 만 성중이염 수술 후 이관의 기능이 정상인지 확인할 수 있었 고, 이를 이용하면 술 후 건강한 중이강의 회복과정 및 회복 정도를 추정할 수 있을 것이며 술 전에 술 후 성공여부 평가 에도 도움이 될 것으로 생각된다. 향후 술 후 정상 고실도와 술전 관련인자와의 추가 비교연구를 통해 보다 정확히 술 후 결과를 예측할 수 있는 예후인자들을 규명할 수 있을 것으 로 생각되고, 이를 통해 의사는 술 후 예후에 대해 환자나 보 호자에게 보다 자세히 설명할 수 있고, 올바른 치료방법을 선택할 때 도움을 줄 수 있을 것으로 사료된다.

\section{Acknowledgments}

This study was supported by the National Research Foundation of Korea (NRF) grant funded by the Korean Government (2018R1 D1A1B07045305).

\section{ORCID}

Hyung-Jong Kim https://orcid.org/0000-0001-9020-6026

\section{REFERENCES}

1) Paparella MM, Meyerhoff WL, Morris MS, DA Costa SS. Mastoidectomy and tympanoplasty. In: Paparella MM, Shumrick DA, Gluckman JL, Meyerhoff WL, editors. Otolaryngology. 3rd ed. Philadelphia, WB: Saunders company;1991. p1417-39.

2) Korean Journal of Otolaryngology-Head and Neck Surgery. Korean society of otorhinolaryngology-head and neck surgery otorhinolaryngology-head and neck surgery: Otology. 2nd ed. Paju: Koonja;2018.

3) Sung CM, Kim HY, Park JM, Lee SS, Cho HH, Cho, YB. The effect of mastoidectomy combined with tympanoplasty type I on postoperative hearing in chronic otitis media patients older than 65 years. Korean J Otorhinolaryngol-Head Neck Surg 2002;45(12): $1130-5$.

4) Kim CS, Kin DW, Hwang CH, Ahn SH, Park HJ, Kim CH. Postoperative results of tympanoplasty type 1 in adult. Korean J Otorhinolaryngol-Head Neck Surg 2017;60(12):626-32.

5) Jerger J. Clinical experience with impedance audiometry. Arch Otolaryngol 1970;92(4):311-24.

6) Yue YS, Kim SH, Lee KC, Chu KC. A clinical study on the prognostic factors of tympanoplasty using postoperative tympanogram in chronic otitis media. Korean J Otorhinolaryngol-Head Neck Surg 1991;34(1):22-7.

7) Ha SL, Chae GH, Yoon TH. A short-term and long-term follow-up study on change of hearing and tympanogram after tympanoplasty type 1. Korean J Otorhinolaryngol-Head Neck Surg 1998;41(11): 1400-5.

8) Albu S, Babighian G, Trabalzini F. Prognostic factors in tympanoplasty. Am J Otol 1998;19(2):136-40.

9) Magnuson B, Falk B. Physiology of the eustachian tube and middle ear pressure regulation. In: Jahn AF, Santos-Sacchi J, editors. Physiology of the Ear. 1st ed. New York: Raven Press;1988. p.24455.

10) Hergils L, Magnuson B. Human middle ear gas composition studied 
by mass spectrometry. Acta Otolaryngol 1990;110(1-2):92-9.

11) Chae SW, Lee KS. The preoperative prognostic factors in chronic otitis media. Korean J Otorhinolaryngol-Head Neck Surg 1993;36: 490-7.

12) Manning SC, Cantekin EI, Kenna MA, Bluestone CD. Prognostic value of eustachian tube function in pediatric tympanoplasty. Laryngoscope 1987;97(9):1012-6.

13) Yoon TH, Yang DS. The influencing factors for short-term hearing results in tympanoplasty type I. Korean J Otorhinolaryngol-Head Neck Surg 1995;38:1510-5.

14) Lee SS, Jeon SJ, Hwang CH, Park JB, Jung YH, Won TB, et al. Surgical results of adult choesteatoma. Korean J Otolaryngol 2001; 44:1043-7.

15) Ojala K, Sorri M. Late post-operative hearing results correlated with the severity of tissue changes in ears with chronic otitis media. J Laryngol Otol 1983;97(2):131-9. 